\title{
Biopsychosocial and Economic Determinants of Low Birth Weight in Jambi, South Sumatera: Path Analysis
}

\author{
Iga Trisnawati1), Harsono Salimo²), Bhisma Murti1) \\ 1)Masters Program in Public Health, Universitas Sebelas Maret \\ ${ }^{2)}$ Department of Pediatrics, Dr. Moewardi Hospital, Surakarta
}

\begin{abstract}
Background: Low birth weight (LBW) is one of the main risk factors of neonatal mortality and morbidity. It is an important public health issue particularly in developing countries. Worldwide, LBW shares around 15-20\% of birth outcome. In Indonesia, LBW shares about $10.2 \%$ of birth outcome. In theory, the risk factors of LBW include not only biological aspect but also psychosocial and economic aspects. This study sought to estimate the biopsychosocial and economic determinants of LBW in Jambi, South Sumatera, using path analysis approach.

Subjects and Method: This was an analytic observational study with case control design. The study was carried out at 20 community health centers in Jambi, South Sumatera, from December 2017 to January 2018. A total sample of 200 newborn infants consisting of 50 LBW and 150 normal birth weight newborn infants were selected for this study by fixed disease sampling. The dependent variable was birth weight. The independent variables were gestational age, infant sex, maternal mid-upper arm circumference (MUAC), maternal gestational stress, maternal education, family income at gestational period, and sanitation. Data on birth weight and MUAC were taken from obstetric record. The other data were collected by questionnaire. The data were analyzed by path analysis.
\end{abstract}

Results: The risk of LBW directly decreased with gestational age $\geq 37$ weeks $(b=-5.06 ; 95 \% \mathrm{CI}=-$ 6.49 to $-3.62 ; \mathrm{p}<0.001)$, male sex $(\mathrm{b}=-0.99 ; 95 \% \mathrm{CI}=-2.12$ to $-0.12 ; \mathrm{p}=0.081)$, low maternal stress $(b=-2.35 ; 95 \% C I=14.01$ to $-0.70 ; p=0.005)$, and good sanitation $(b=-1.04 ; 95 \% \mathrm{CI}=-2.13$ to $0.05 ; \mathrm{p}=0.062)$. Gestational age increased with family income $(\mathrm{b}=1.74 ; 95 \% \mathrm{CI}=0.96$ to 2.52 ; $\mathrm{p}<0.001)$. Low maternal stress was positively affected by high family income $(b=1.34 ; 95 \% \mathrm{CI}=$ 0.197 to $2.50 ; \mathrm{p}=0.022)$. Good sanitation was positively affected by high family income $(b=0.71$; $95 \% \mathrm{CI}=0.01$ to $1.41 ; \mathrm{p}=0.046)$. High family income was positively affected by high education level $(\mathrm{b}=1.37 ; 95 \% \mathrm{CI}=0.57$ to $2.18 ; \mathrm{p}=0.001)$

Conclusion: The risk of LBW directly decreases with gestational age $\geq 37$ weeks, male sex, low maternal stress, and good sanitation. LBW is indirectly affected by maternal education and family income.

Keywords: biopsychosocial, economic, determinant, LBW

\section{Correspondence:}

Iga Trisnawati. Masters Program in Public Health, Universitas Sebelas Maret, Jl. Ir. Sutami 36 A, Surakarta 57126, Central Java. Email: trisnawatiiga27@gmail.com. Mobile: +6282377277992.

\section{BACKGROUND}

Birth weight is a significant predictor of the newborn and future health status (Shrestha et al., 2016; Ahankari et al., 2017; Mahumud et al., 2017). Low birth weight is a major public health problem, especially in developing countries. It is a risk factor for early neonatal mortality and morbidity
(Mahumud et al., 2017). The World Health Organization (WHO) reports as many as 15$20 \%$ of all infants worldwide are born with low birth weight, representing more than 20 million births annually, of which about 95\% are from developing countries (WHO, 2014; Ahankari et al., 2017). 
Basic Health Research Results of 2013 estimated the percentage of low birth weight in Indonesia by $10.2 \%$ (Ministry of Health Indonesia, 2015). In Jambi city, the number of infants with low birth weight was 70 infants in 2016, which increased by 40\%. Low birth weight was the leading cause of neonatal mortality in Jambi from 2015-2016. Other major causes of neonatal death in 2016 were asphyxia, infection or sepsis, and other causes (Municipality Health Jambi, 2017).

The birth of a low birth weight baby has both short-term and long-term consequences. Short-term effects include neonatal, morbidity and disability in infants and children (WHO, 2014, WHO, 2017). Long-term impacts are growth barriers (eg, stunting) (Aryastami et al., 2017), poor cognitive development, increased risk of chronic illness (WHO, 2014), and adult health status (WHO, 2017). In addition, low birth weight provides a burden in the future for the community as a whole and requires greater health costs (Mahumud et al., 2017; WHO, 2017). Low birth weight has both short-term and long-term consequences. Short-term effects include neonatal, morbidity and disability in infants and children (WHO, 2014, WHO, 2017). Long-term impacts include growth retardation (eg, stunting) (Aryastami et al., 2017), poor cognitive development, increased risk of chronic illness in the adult age (WHO, 2014), and adult health status (WHO, 2017). In addition, the low birth weight causes a burden to the community as a whole and greater health costs (Mahumud et al., 2017; WHO, 2017).

Low birth weight may be caused by biological, psychological, and socioeconomic factors (Mahumud et al., 2017). Based on this background, this study aimed to examine the economic and biopsychosocial determinants of low birth weight incidence in Jambi city, Sumatera, Indonesia.

\section{SUBJECTS AND METHOD \\ 1. Study Design}

This was an analytic observational study with a case control design. The study was conducted at 20 community health centers in Jambi, Sumatera, Indonesia, from December 2017 to January 2018.

\section{Population and Sample}

Target population was infants with low birthweight. Soure population was infants with low birth weight in Jambi. A sample of 200 infants consisting of 50 infants with low birth weight (case) and 150 infants with normal birth weight (control) was selected for this study by fixed disease sampling.

The exclusion criteria were gemelli, subjects who did not reside in Jambi, Sumatera, and subjects who refused to participate in the study.

\section{Study Variables}

The dependent variable was low birth weight. The independent variables were maternal Middle Upper Arm Circumference (MUAC), gestational age, sex, psychological stress during pregnancy, environmental sanitation, maternal education, and family income.

\section{Operational Definition of Variables}

Low birth weight was defined as an infant with birth weight less than 2,500 grams. Birth weight was measured at birth and weighed using a baby scale. The data were taken from maternal and child health monitoring book. The measurement scale was continuous, but for the purpose of data analysis it was transformed into dichotomous coded o for low birth weigth $<2,500 \mathrm{~g}$ and 1 for normal birth weight $\geq 2,500 \mathrm{~g}$.

Maternal nutritional status was defined as maternal MUAC during pregnancy. Maternal MUAC was measured using mea- 
suring tape and recorded in the maternal and child health monitoring book. Measurement scale was continuous, but for the purpose of data analysis it was transformed into dichotomous coded o for MUAC <25.5 $\mathrm{cm}$ and 1 for MUAC $\geq 23.5 \mathrm{~cm}$.

Gestational age was defined as the length of time the fetus is in the uterine. It was calculated from the first day of the last menstrual period to the day of birth. The measurement scale was continuous, but for the purpose of data analysis it was transformed into dichotomous coded o for $<37$ weeks and 1 for $\geq 37$ weeks.

Sex was defined as the biological sexual identity from birth. The measurement scale was dichotomous coded o for male and 1 for female.

Psychological stress during pregnancy was defined as feeling of distress resulting from changes in financial condition, family problem, shifting concern, loss of value, concern about pregnancy, physical, sexual or emotional abuse, alcohol or drug use, or excessive burden at work. The data were collected using The Psychosocial Profile Stress Scale by Curry et al. (1998). The measurement scale was continuous, but for the purpose of data analysis it was transformed into dichotomous coded o (low stress) if score $<20$ and 1 (high stress) if score $\geq 20$.

Environment sanitation was defined as effort undertaken to control the environment based on the reference of Regulation of the Minister of Health of the Republic of Indonesia No. 3 of 2014 on total community based environmental sanitation, including Stop Open Defecation ("Stop BABS”), washing hands with soap, drinking water management and household food, securing household waste and ensuring household waste water. The measurement scale was continuous, but for the purpose of data analysis it was transformed into dicho- tomous coded o for score <mean and 1 for score $\geq$ mean.

Maternal education was defined as the highest scholar achievement by the study subject based on the ownership of the last diploma at the time of the study. The measurement scale was categorical, coded o < senior high school and $1 \geq$ senior high school.

Family income was defined as the total amount of family income earned from the income of the head of the household and the income of the mother, either from the regular or sideline income per month and expressed in rupiah currency. The measurement scale was continuous, but for the purpose of data analysis it was transformed into dichotomous coded $\mathrm{o}$ if $<$ minimum regional wage $(\operatorname{Rp} 1,906,650)$ and 1 if $\geq$ minimum regional wage $(\operatorname{Rp} 1,906,650)$.

\section{Data Collection Instrument}

The data were taken from medical record, maternal and child health monitoring book, and questionnaire.

\section{Data Analysis}

Sample characteristics were describe by univariate analysis. Bivariate analysis used Chi square. Multivariate analysis used path analysis to determine the direct and indirect effects of the relationships between study variables. Path analysis steps included model specification, model identification, model fit, parameter estimate, and model respecification.

\section{Research Ethics}

The research ethical clearance was obtained from the Research Ethics Committee at Dr. Moewardi Hospital, Surakarta, Central Java, Indonesia. Research ethics included issues such as informed consent, anonymity, confidentiality, and ethical clearance. 
Journal of Maternal and Child Health (2018), 3(1): 1-10

https://doi.org/10.26911/thejmch.2018.03.01.01

\begin{tabular}{l}
\hline RESULTS \\
\hline 1. Sample Characteristics \\
Table 1 shows that $142(80.7 \%)$ infants with \\
normal birth weight were born from \\
mothers with MUAC $\geq 23.5 \mathrm{~cm}$. As many as \\
$35(92.1 \%)$ LBW infants were born at $<37$ \\
weeks gestation. As many as $27(27.8 \%)$ of \\
the LBW infants were female.
\end{tabular}

As many as 41 (21.9\%) of mothers who experienced low stress during pregnancy gave birth LBW infants. As many as 32 (39\%) of LBW infants came from families with poor sanitation and 27 (67.5\%) came from low income families. Normal birth weight infants were born mostly by Table 1. Distribution of sample characteristics

\begin{tabular}{|c|c|c|c|c|c|}
\hline \multirow{2}{*}{ No } & \multirow{2}{*}{ Characteristics } & \multicolumn{2}{|c|}{ Case } & \multicolumn{2}{|c|}{ Control } \\
\hline & & $\mathbf{N}$ & $\%$ & $\mathbf{N}$ & $\%$ \\
\hline \multirow[t]{3}{*}{1.} & Maternal MUAC & & & & \\
\hline & Maternal MUAC $<23.5 \mathrm{~cm}$ & 16 & 66.7 & 8 & $33 \cdot 3$ \\
\hline & Maternal MUAC $\geq 23.5 \mathrm{~cm}$ & 34 & 19.3 & 142 & 80.7 \\
\hline \multirow[t]{3}{*}{2.} & Gestational Age & & & & \\
\hline & Gestational age $<37$ weeks & 35 & 92.1 & 3 & 7.9 \\
\hline & Gestational age $\geq 37$ weeks & 15 & $9 \cdot 3$ & 147 & 90.7 \\
\hline \multirow[t]{3}{*}{3.} & Sex of baby & & & & \\
\hline & Male & 23 & 22.3 & 80 & 77.7 \\
\hline & Female & 27 & 27.8 & 70 & 72.2 \\
\hline \multirow{3}{*}{4.} & Psychological stress during pregnancy & & & & \\
\hline & Low maternal stress $(<20)$ & 41 & 21.9 & 146 & 78.1 \\
\hline & High maternal stress $(\geq 20)$ & 9 & 69.2 & 4 & 30.8 \\
\hline \multirow[t]{3}{*}{5} & Environment sanitation & & & & \\
\hline & Poor sanitation $(<15)$ & 32 & 39 & 50 & 61 \\
\hline & Good sanitation $(\geq 15)$ & 18 & 15.5 & 100 & 84.7 \\
\hline \multirow[t]{3}{*}{6.} & Maternal education & & & & \\
\hline & Maternal education $<$ Senior High School & 14 & 42.4 & 19 & 57.6 \\
\hline & Maternal education $\geq$ Senior high school & 36 & 21.7 & 130 & 78.3 \\
\hline \multirow[t]{3}{*}{$7 \cdot$} & Family income & & & & \\
\hline & Low family income $<$ Rp 1,906,605 & 27 & 67.5 & 13 & 32.5 \\
\hline & High family income $\geq \mathrm{Rp} 1,906,650$ & 23 & 14.4 & 137 & 85.6 \\
\hline
\end{tabular}

\section{Path Analysis}

The number of observed variables were 8 , endogenous variables were 6 , and exogenous variables were 2 . Therefore, degree of freedom (df) value were 19, so it can conclude that degree of freedom was over identified and path analysis can be done. Figure 1 shows the structural model with estimation. Table 2 shows the results of path analysis on the biopsychosocial economic determinants of low birth weight.

Table 2 shows that the risk of low birthweight decreased with higher gestational age $(b=-5.06 ; 95 \% \mathrm{CI}=-6.49$ to 3.62; $\mathrm{p}<0.001)$, male sex $(b=-0.99 ; 95 \%$
$\mathrm{CI}=-2.12$ to $-0.12 ; \mathrm{p}=0.081)$, low psychological stress during pregnancy $(b=-2.35$; $95 \% \mathrm{CI}=14.01$ to $-0.70 ; \mathrm{p}=0.005)$, and good environmental sanitation $(b=-1.04$; 95\% CI=-2.13 to $-0.05 ; \mathrm{p}=0.062$ ).

Gestational age $(b=1.74 ; 95 \% \mathrm{CI}=$ 0.96 to $2.52 ; \mathrm{p}<0.001)$ increased with family income. High family income increased the likelihood of low stress $(b=$ $1.34 ; 95 \% \mathrm{CI}=0.20$ to $2.50 ; \mathrm{p}=0.022$ ), good environmental santitation $(b=0.71$; 95\% $\mathrm{CI}=0.01$ to $1.41 ; \mathrm{p}=0.046)$, and maternal MUAC $\geq 23.5 \mathrm{~cm}(\mathrm{~b}=1.45 ; 95 \%$ $\mathrm{CI}=0.56$ to $2.35 ; \mathrm{p}=0.001)$. Education level $\geq$ senior high school was more likely to 
have high family income $(b=1.37$ CI $95 \%=\quad 0.57$ to $2.18 ; p=0.001)$.

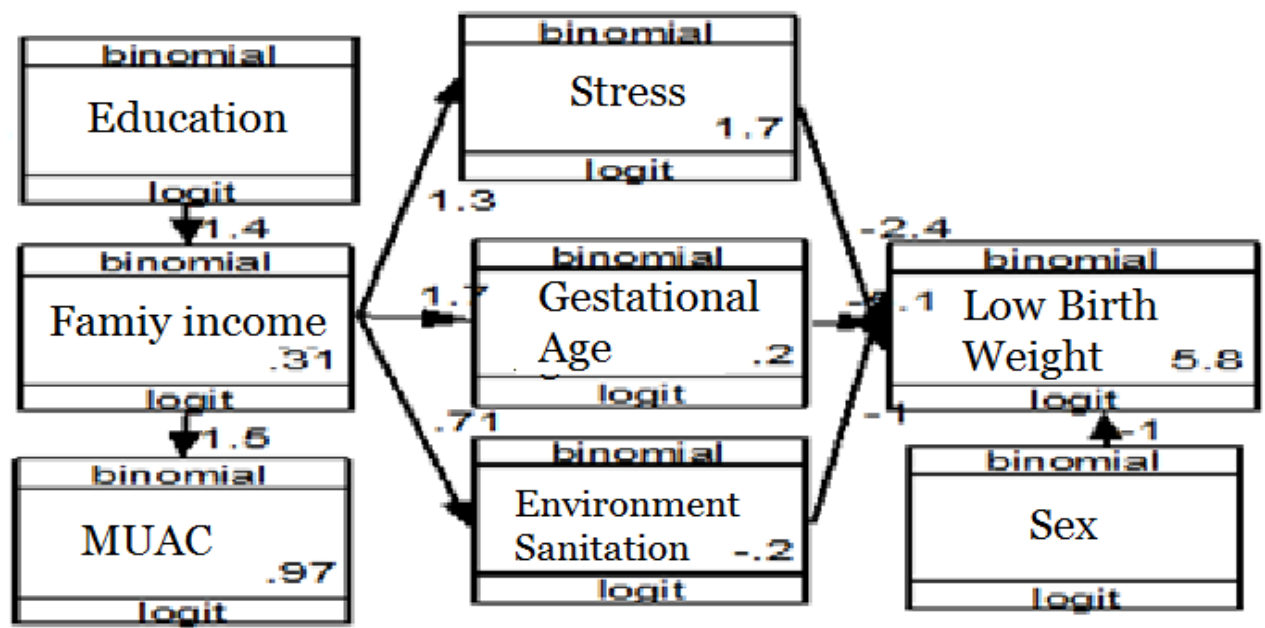

Figure 1. Path structural model with parameter estimates

Table 2. The results of path analysis on the biopsychosocial and economic determinants of low birth weight

\begin{tabular}{|c|c|c|c|c|c|c|}
\hline \multirow[b]{2}{*}{$\begin{array}{c}\text { Dependent } \\
\text { variable }\end{array}$} & \multirow{2}{*}{\multicolumn{2}{|c|}{ Independent variable }} & \multirow{2}{*}{$\begin{array}{c}\text { Path } \\
\text { coefficient } \\
\text { (b) }\end{array}$} & \multicolumn{2}{|c|}{$95 \%$ CI } & \multirow[b]{2}{*}{$\mathbf{p}$} \\
\hline & & & & $\begin{array}{c}\text { Lower } \\
\text { limit }\end{array}$ & $\begin{array}{l}\text { Upper } \\
\text { limit }\end{array}$ & \\
\hline \multicolumn{7}{|l|}{ Direct Effect } \\
\hline Birth weight $<2,500 \mathrm{~g}$ & $\leftarrow$ & $\begin{array}{l}\text { Gestational age ( } \geq 37 \\
\text { weeks) }\end{array}$ & -5.06 & -6.49 & -3.62 & $<0.001$ \\
\hline Birth weight $<2,500 \mathrm{~g}$ & $\leftarrow$ & Male sex & -0.99 & -2.12 & -0.12 & 0.081 \\
\hline Birth weight $<2,500 \mathrm{~g}$ & $\leftarrow$ & $\begin{array}{l}\text { Low psychological stress } \\
\text { during pregnancy }\end{array}$ & -2.35 & -4.01 & -0.70 & 0.005 \\
\hline Birth weight $<2,500 \mathrm{~g}$ & $\leftarrow$ & $\begin{array}{l}\text { Good environment } \\
\text { sanitation }\end{array}$ & -1.04 & -2.13 & -0.05 & 0.062 \\
\hline \multicolumn{7}{|l|}{ Indirect Effect } \\
\hline $\begin{array}{l}\text { Gestational age ( } \geq 37 \\
\text { weeks) }\end{array}$ & $\leftarrow$ & $\begin{array}{l}\text { Family income } \geq \\
\text { Rp 1,906,650 }\end{array}$ & 1.74 & 0.96 & 2.52 & $<0.001$ \\
\hline $\begin{array}{l}\text { Low psychological } \\
\text { stress during pre } \\
\text { gnancy }\end{array}$ & $\leftarrow$ & $\begin{array}{l}\text { Family income } \geq \\
\text { Rp 1,906,650 }\end{array}$ & 1.34 & 0.19 & 2.50 & 0.022 \\
\hline $\begin{array}{l}\text { Good environment } \\
\text { sanitation }\end{array}$ & $\leftarrow$ & $\begin{array}{l}\text { Family income } \geq \\
\text { Rp 1,906,650 }\end{array}$ & 0.71 & 0.01 & 1.41 & 0.046 \\
\hline $\begin{array}{l}\text { Maternal MUAC } \geq \\
23.5 \mathrm{~cm}\end{array}$ & $\leftarrow$ & $\begin{array}{l}\text { Family income } \geq \\
\text { Rp } 1,906,650\end{array}$ & 1.45 & 0.55 & 2.35 & 0.001 \\
\hline $\begin{array}{l}\text { Family income } \geq \mathrm{Rp} \\
1,906,650 \\
\text { N observation }=200 \\
\text { Log Likelihood }=-481.75\end{array}$ & $\leftarrow$ & $\begin{array}{l}\text { Maternal education } \geq \\
\text { Senior high school }\end{array}$ & 1.37 & 0.57 & 2.18 & 0.001 \\
\hline
\end{tabular}

\section{DISCUSSION}

1. The relationship between gestational age and low birth weight

The current study showed that term pregnancy ( $\geq 37$ weeks) lowered the risk of low birthweight. This study supports the previous finding by Wang et al (2017) that gestational age $\geq 37$ weeks decreased the risk of low birth weight. This study is also consistent with Sebayang et al. (2012), 
which found the shorter gestation period, the higher risk of LBW.

Another study added more evidence, which showed that gestational age $<37$ weeks had twice as many risk of low birth weight than gestational age $\geq 37$ weeks. Gestational age 28-34 weeks had 6 times as many risk of low birth weight than gestational age $\geq 37$ weeks (Chibwasha et al., 2016).

According to Soetjiningsih and Ranuh (2016), in the fetal growth and development, a fetus aged 8 months has only $1,500 \mathrm{~g}$ body weight. Generally, preterm fetus (<37 weeks gestational age) has only $<2,500$ gram body weight.

\section{The relationship between sex and low birth weight}

The current study showed that female had higher risk of low birth weight than male. It is supported by Soetjiningsih dan Ranuh (2016), which stated that sex was one of factors affecting fetal growth and development.

This study is also consistent with previous study, which found that female fetus had an increased risk of the low birth weight (Andayasari and Opitasari, 2016; Kader and Perera, 2014; Momeni et al., 2017; Setyo and Paramita, 2015; Sebayang et al., 2012; Taywade and Pisudde, 2017).

It is because female fetus has lower body weight than male fetus for the same gestational age, so that female fetus has a higher risk of low birth weight (Setyo and Paramita, 2015).

\section{The relationship between psycho- logical stress and low birth weight} The current study found that low stress in pregnancy lowered the risk of low birth weight. Studies by Schetter (2011), TanduUmba et al. (2014), Nurahmawati et al (2017), and Nurmayanti et al (2017) found that infants with low birth weight had been mostly born by mothers with experience of considerable amount of stress in pregnancy.

According to Tandu-Umba et al. (2014) stress during pregnancy can induce maternal health problem such as prematur delivery. Janiwarty and Pieter (2013) added that stress during pregnancy include negative and fear feelings, which can affect the fetal physiologic and psychologic development. In addition, stress during pregnancy can lead to increased maternal blood pressure, which eventually can hamper the nutritional intake and constrain the fetal growth (Lau, 2013).

Stress during pregnancy may also affect appetite, eating frequency patterns, and weight gain. All of these factors may play an important role in fetal growth and increased the risk of LBW (Lau, 2013).

Pregnant women are advised to consult with medical personnel or the closest people who can be trusted if they have problems during pregnancy so as not to burden their mind that eventually can interfere with the fetal growth in the womb.

\section{The relationship between environ- ment sanitation and low birth weight}

The results showed that a good environmental sanitation was associated with a decreased risk of infant with low birth weight. This finding is in line with the study result by Demelash et al. (2015) and Taywade and Pisudde (2017), which reported that poor physical environmental sanitation increased the risk of low birth weight.

Environmental sanitation is a strategy for management development in health care (Yindong et al., 2017). This study suggested pregnant women have hygienic and environmental sanitation behaviors as well as government-defined programs called community-based total sanitation. Medical personnel is expected to improve the achievement of community-based total 
sanitation by improving the quality and quantity of health education to the community and improving observation and evaluation on a regular basis.

\section{The relationship between family income and low birth weigth through gestational age}

This study indicated that high family income lowered the risk of infants with low birth weight. Low income and rising living costs can hamper pregnant women from fulfilling the needs for nutrition and health care. In turn, low income can increase the risk of low birth weight (Sebayang et al., 2012; Kayode et al., 2014; Demelash et al., 2015; Mahumud et al., 2017; Taywade and Pisudde, 2017).

\section{The relationship between family income and low birth weight}

This study showed that high family income lowered the risk of low birth weight via low stress during pregnancy.

This finding is consistent with studies by Islam and ElSayed (2015) and Setyo and Paramita (2015), which reported that maternal employment increased family income, lowered stress during pregnancy, andeventually increased the risk of delivering infants with low birth weight.

According to Oltmans dan Emery (2013), pregnant mothers with stress may experience eating disorder and increased blood pressure, which interrupt nutrition transfer from mother to fetus.

\section{The relationship between family income and low birth weight}

This study indicates that family income increases the risk of LBW infants through environmental sanitation. Low family income will cause poor environmental sanitation, thus increasing the risk of LBW.

\section{The relationship between family income and maternal MUAC}

This study shows that family income can affect Mother MUAC. Low family income will cause difficulties in meeting nutritional needs (Setyo and Paramita, 2015). Maternal nutrition before pregnancy greatly affects the nutritional status of the mother and the fetus it contains (Sulistyoningsih, 2011). Mild nutritional status may lead to impaired fetal growth, delivering low birth weight infants, and will subsequently affect intergenerational malnutrition (Fikawati et al., 2015).

Inadequate protein-energy intake in pregnant women can lead to Chronic Energy Deficiency (CED), which is characterized by MUAC $<23.5 \mathrm{~cm}$. Pregnant women with CED have the higher risk for low birth weight (Ministry of Health, 2016).

This study is consistent with the results of a study by Sebayang et al. (2012), which states that mothers who have an upper arm circumference of less than 23.5 $\mathrm{cm}$ have a greater risk of having low birth weight infants. Similarly, the results of a study by Assefa et al. (2012) reported that the MUAC of less than $23 \mathrm{~cm}$ increased the incidence of infants with LBW.

\section{The relationship between maternal education on low birth weight}

This study shows that education can affect the incidence of infants with low birth weight through income. Education level is a risk factor for infants with low birth weight. Lack of formal education may increase the incidence of low birth weight (Sebayang et al., 2012; Mahmoodi et al., 2013; Kader and Perera, 2014; Demelash et al., 2015; Islam and ElSayed, 2015; Khayati et al., 2016; Momeni et al., 2017; Nurahmawati et al., 2017).

Education level is a risk factor for low birth weight. Education level can affect the perceptions of pregnant women and the community on various activities including health activities and behaviors such as the practice of feeding pregnant women and 
the utilization of health services (Demelash et al., 2015).

\section{CONFLICT OF INTEREST}

None declare.

\section{REFERENCE}

Ahankari A, Bapat S, Myles P, Fogarty A, Tata L (2017). Factors associated with preterm delivery and low birth weight: a study from rural Maharashtra, India. F100oResearch, 6 (May), 72. https://doi.org/10.12688/f10ooresearch.10659.1.

Andayasari L, Opitasari C (2016). Parity and risk of low birth weight infant in full term pregnancy, 7(1): 13-16.

Aryastami NK, Shankar A, Kusumawardani N, Besral B, Jahari AB (2017). Low birth weight was the most dominant predictor associated with stunting among children aged 1223 months in Indonesia,1-6.https://doi.org/10. 1186/s40795-017-0130-x.

Assefa N, Berhane Y, Worku A (2012). Wealth status, mid upper arm circumference (MUAC) and antenatal care (ANC) are determinants for low birth weight in Kersa, Ethiopia, 7(6). https://doi.org/10.1371/journal.pone. o039957.

Chibwesha CJ et al. (2016). Predictors and outcomes of low birth weight in Lusaka, Zambia, International Journal of Gynecology and Obstetrics. International Federation of Gynecology and Obstetrics, 134(3): 309-314. doi: 10.1016/j.ijgo.2016.03.021.

Demelash H, Motbainor A, Nigatu D, Gashaw K, Melese A (2015). Risk factors for low birth weight in Bale zone hospitals, South-East Ethiopia: a case -control study. BMC Pregnancy and Childbirth,1-10. https://doi.org/10. 1186/s12884-015-0677-y.
Dinas Kesehatan Kota Jambi (2017). Data angka kematian ibu dan angka kematian bayi di Kota Jambi Tahun 2015 dan Tahun 2016. Jambi.

Fikawati S, Syafiq A, Karima K (2015). Gizi ibu dan bayi. Jakarta: PT. Rajagrafindo Persada.

Islam MM, ElSayed MK (2015.) Pattern and determinants of birth weight in Oman. Public Health. 129(22): 16181626.

Janiwarty B, Pieter HZ (2013). Pendidikan psikologi untuk bidan - suatu teori dan terapannya. Yogyakarta: Andi Offset.

Kader M, Perera NKP (2014). Socio-economic and nutritional determinants of low birth weight in India, 6(7), 1-8. https://doi.org/10.4103/1947-2714. 136902.

Kayode GA, Amoakoh-coleman M, Agyepong IA, Ansah E, Grobbee, DE, Klipstein-grobusch K (2015). Contextual risk factors for low birth weight: a multilevel analysis, 9(10), 1-8. https://doi.org/10.1371/journal.pone.0109333.

Kementerian Kesehatan RI (2015). Profil Kesehatan Indonesia 2014. Jakarta. (2016). Profil Kesehatan Indonesia Tahun 2015. Jakarta.

Khayati YN, Prayitno A, \& Poncorini E. (2016). Multilevel analysis on the factors associated with low birth weight in Temanggung, Central Java, 7-12.

Lau Y (2013). The effect of maternal stress and health-related quality of life on birth, 27(1), 14-24. https://doi.org/ 10.1097/JPN.obo13e31824473b9

Mahmoodi Z, Karimlou M, Sajjadi H, Dejman M, Dolatian M (2013). Working conditions, socioeconomic factors and low birth weight: path analysis, 15(9). https://doi.org/10.5812/ircmj. 11449 . 
Mahumud RA, Sultana M, Sarker AR (2017). Distribution and determinants of low birth weight in developing countries. 18-28.

Momeni M, Danaei M, Jabbari A, Kermani N, Bakhshandeh M, Foroodnia S, Safizadeh $H$ (2017). Prevalence and risk factors of low birth weight in the Southeast of Iran, O-4. https:// doi.org/10.4103/ijpvm.IJPVM.

Nurahmawati D, Salimo H, \& Dewi YLR. (2017). Effects of maternal education, psychosocial stress, nutritional status at pregnancy, and family income, on birthweight in Nganjuk, East Java, 257, 327-337.

Nurmayanti R, Salimo H, Dewi YLR. (2017). Effects of maternal nutrition status, maternal education, maternal stress, and family income on birthweight and body length at birth in Klaten, Central Java, 2, 300-311.

Oltmans TF, Emery RE (2012). Psikologi abnormal. Yogyakarta: Penerbit Pustaka Pelajar.

Roland MCP, Friis CM, Godang K, Bollerslev J, Haugen G, Henriksen T (2014). Maternal factors associated with fetal growth and birthweight are independent determinants of placental weight and exhibit differential effects by fetal sex, 9(2): 1-5. https://doi.org/10.1371/journal.pone.0o87303.

Schetter CD (2011). Psychological science on pregnancy: stress processes, biopsychosocial models, and emerging research issues. https://doi.org/10. 1146/annurev.psych.031809.130727.

Sebayang SK, Dibley MJ, Kelly PJ, Shankar AV Shankar AH (2012). Determinants of low birthweight, small-for-gestational-age and preterm birth in Lombok, Indonesia: analyses of the birthweight cohort of the SUMMIT trial, 17(8),
938-950. https://doi.org/10.1111/ j.1365-3156.2012.03039.x.

Setyo M, Paramita A (2015). Pola kejadian dan determinan bayi dengan Berat badan lahir rendah (BBLR) di Indonesia tahun 2013 (Pattern of Occurrence and Determinants of Baby. 1-10.

Shrestha M, Gupta SK, Sarmah BK, Baidya $M$ (2016). Socio economic and maternal reproductive factors affecting low birth weight babies in Central Nepal. Journal Nepal Paediatric Soc. 36(3).

Soetjiningsih, Ranuh IGNG (2016). Tumbuh kembang anak. Edisi 2. Jakarta: Penerbit Buku Kedokteran EGC.

Sulistyoningsih H (2011). Gizi untuk kesehatan ibu dan anak. Yogyakarta: Graha Ilmu.

Tandu-Umba B, Dedetemo DK, Mananga, GL (2014). Maternal stress and pregnancy outcomes, 361-370.

Taywade ML, Pisudde PM (2016). Science direct study of sociodemographic determinants of low birth weight in Wardha district, India. Clinical Epidemiology and Global Health, 1-7. https://doi.org/10.1016/-j.cegh.2016. 07.001.

Wang J, Zeng Y, Ni Z, Wang G, Liu S (2017). Risk factors for low birth weight and preterm birth. 37(2), 286292. https://doi.org/10.1007/s11596017-1729-5.

WHO (2014). Global nutrition target 2025 low birth weight policy brief. Geneva. (2017). Feto-maternal nutrition and low birth weight. Geneva: WHO. Tersedia pada : http://www.who.int/nutrition/topics/feto_maternal/en/, diakses pada tanggal 7 Juli 2017.

Yindong T, Xiaoge B, Cen C, Xi Y, Yiren L, Huijiao L, Xuejun W (2017). Science of the total environment impacts of sanitation improvement on reduction 
Journal of Maternal and Child Health (2018), 3(1): 1-10

https://doi.org/10.26911/thejmch.2018.03.01.01

of nitrogen discharges entering the environment from human excreta in

doi. org/10.1016/j.scitotenv.2017.03China. Science of the Total Environ.177 .

ment, 593-594: 439-448. https://- 